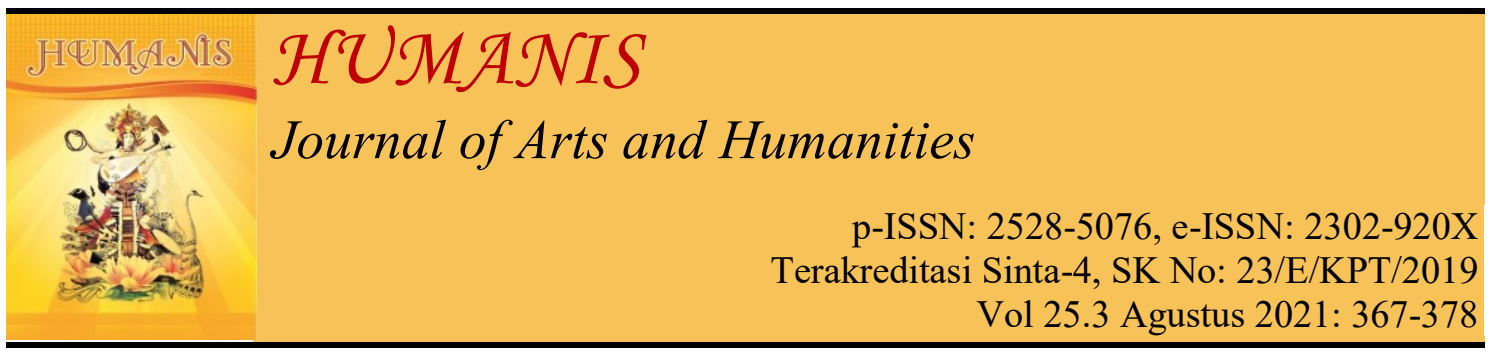

\title{
Ketidakefektifan Kalimat dalam Surat Pembaca Bali Post Periode Januari--Agustus 2020
}

\author{
Riza Milinia Vrindi Khusnika, I Nyoman Suparwa \\ Universitas Udayana, Denpasar, Bali Indonesia \\ rizamilinia0104@gmail.com, nym_suparwa@unud.ac.id
}

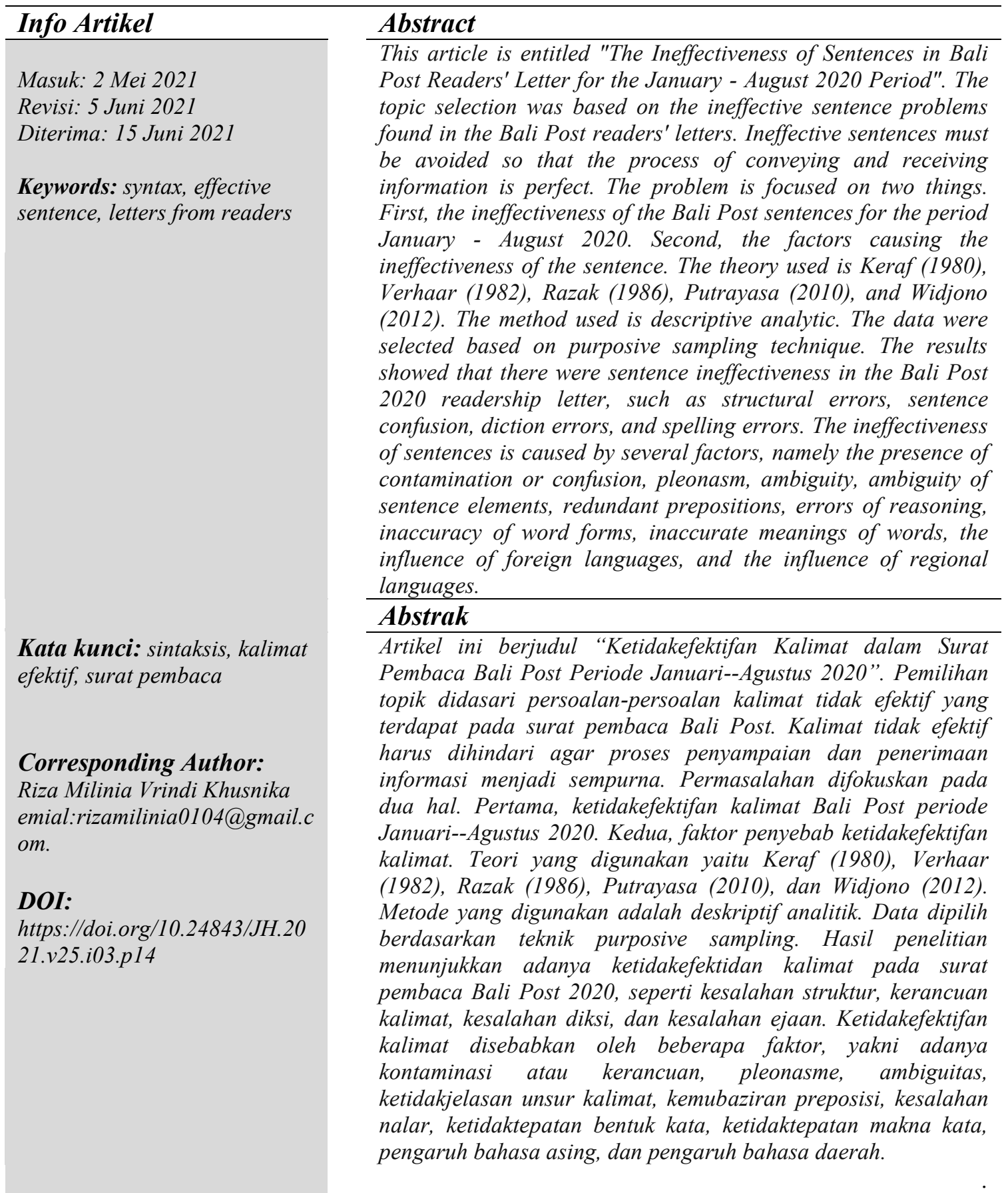




\section{PENDAHULUAN}

Manusia tidak dapat dilepaskan dari komunikasi. Komunikasi adalah penerimaan sebuah pesan atau berita antara dua orang atau lebih. Pesan yang disampaikan dapat bersifat lisan atau tertulis. Dalam komunikasi tulis, misalnya diperlukan penyampaian pesan dengan kalimat efektif agar pesan tersampaikan dengan baik. Lain halnya dengan bahasa lisan yang mempunyai beberapa sarana komunikasi, bahasa tulis hanya terdapat satu cara komunikasi antara orang yang berbicara dan yang diajak berbicara, yaitu melalui tulisan (Hariyanto, 2018).

Melalui tulisan penyampai pesan dalam mengirimkan isi pesan dengan baik tanpa harus bertemu dengan penerima pesan. Penting untuk diketahui dalam bahasa tulis adalah penggunaan kalimat. Kridalaksana (2001:97) mengatakan bahwa kalimat adalah satuan bahasa yang relatif berdiri sendiri mempunyai pola intonasi final, baik secara aktual maupun potensial terdiri atas klausa. Dalam kalimat yang diperuntukkan dan diterima terdapat ide, gagasan, pesan, pengertian, dan informasi. Kalimat disebut efektif jika informasi yang disampaikan dapat diterima secara utuh atau sempurna. Widjono (2012:205) menyatakan bahwa kalimat efektif adalah kalimat yang bersifat singkat, padat, jelas, lengkap, dan dapat memberikan informasi secara benar. Putrayasa (2010:2) mengatakan bahwa kalimat efektif adalah kalimat yang dapat menunjukkan gagasan, pikiran, dan perasaan dengan benar yang dapat dilihat dari segi diksi, struktur, dan logikanya. Kalimat efektif dapat diterima secara sempurna oleh pembaca jika isi atau tujuan yang disampaikan jelas dan lengkap. Kalimat yang digunakan ialah kalimat yang ditulis oleh pembaca, kemudian disempurnakan dengan tujuan pembaca lainnya memahami isi surat pembaca. Kalimat yang memiliki pola yang salah menurut tata bahasa disebut kalimat tidak efektif. Kalimat dapat dikatakan efektif jika terdapat persyaratan struktural dari segi pola yang benar. Kalimat memiliki sistem yang bervariasi agar proses penyampaian dan penerimaan menjadi sempurna. Pentingnya peran kalimat efektif dalam penulisan sebuah media yang dipublikasikan untuk khalayak ramai. Pada umumnya masyarakat membutuhkan informasi setiap waktu sehingga sangat diperlukan bila setiap rumah memiliki pesawat televisi atau berlangganan surat kabar (Rahmat, 2017:71). Oleh sebab itu, media cetak digunakan sebagai objek penelitian ini. Media cetak yang digunakan penelitian ini yaitu surat pembaca Bali Post.

Effendy, (1993) mengungkapkan bahwa surat kabar adalah lembaran tercetak yang berisi laporan atau berita yang terjadi di masyarakat dengan ciriciri terbit secara berkala, bersifat umum, yang isinya berdasarkan fakta mengenai apa saja dan di mana saja di seluruh dunia untuk diketahui oleh pembaca. Surat kabar terdiri atas delapan hingga dua belas halaman, baik yang berisi berita terkini, iklan, maupun opini masyarakat. Surat kabar bermanfaat bagi masyarakat untuk mengetahui peristiwa yang terjadi disajikan secara aktual.

Surat kabar memuat halaman khusus surat pembaca yang ditulis oleh pembaca. Selain surat pembaca pada halaman opini surat kabar Bali Post terdapat sebuah tajuk rencana, pankote dan iklan. Surat kabar yang digunakan adalah surat kabar Bali Post. Bali Post terbit sejak 16 Agustus 1948. Bali Post merupakan surat kabar tertua di Bali yang bertempat di Jl. Kepundung No. 67A, Dangin Puri Kaja, Denpasar Utara. Pada tahun 1948 surat kabar Bali Post bernama Suara Indonesia, kemudian tahun 1972 diubah menjadi Bali Post hingga sekarang.

Persoalan dalam penelitian ini dilatarbelakangi alasan surat pembaca dapat dimengerti oleh pembaca, tetapi dari segi fungsi, struktur, dan proses 
kalimat ditemukan kalimat yang tidak efektif. Hal tersebut disebabkan oleh adanya kalimat yang ditulis secara kabur, kacau, tidak logis, atau bertele-tele (Astuti, 2017:43). Kalimat tidak efektif perlu diperbaiki agar menjadi kalimat yang sesuai dengan kaidah tata baku bahasa Indonesia dan Kamus Besar Bahasa Indonesia agar menjadi kalimat yang baik dan benar. Tarigan (2008) mengatakan bahwa surat pembaca dikelompokkan dalam surat pribadi karena mempunyai tanda, yakni bahasa yang digunakan alami, sintaksis seharihari, dan benar-benar tulisan pribadi seseorang.

Dalam penelitian ini diambil data berupa surat pembaca Bali Post, didasarkan atas pertimbangan (1) surat kabar Bali Post merupakan surat kabar umum tertua di Bali terbit sejak 16 Agustus 1948 sehingga secara luas pernah dibaca oleh masyarakat Bali, (2) dalam surat kabar Bali Post terdapat surat pembaca yang dimuat di halaman opini yang menarik dan berisi kritik, saran, tanggapan, keluhan, imbauan, serta pendapat pembaca yang dimuat dalam surat pembaca, (3) ditemukan kalimat yang tidak efektif dalam surat pembaca Bali Post, yang harus dibenarkan sesuai dengan tata baku bahasa Indonesia agar terhindar dari kesalahpahaman terhadap isi yang disampaikan penulis untuk pembaca, dan (4) surat pembaca belum digunakan sebagai objek penelitian oleh peneliti lain.

Surat pembaca Bali Post dipilih karena sejauh ini belum ada yang mengambil bahan penelitian tersebut dengan objek penelitian tentang ketidakefektifan kalimat pada surat pembaca Bali Post tahun 2020. Dalam surat pembaca Bali Post ditemukan 40 data kalimat yang tidak efektif. Dalam kalimat tidak efektif beberapa di antaranya terdapat penempatan kata depan yang salah, kemubaziran kata, dan penggunaan sinonimi yang salah.
Kalimat tidak efektif harus diperbaiki sesuai dengan tata bahasa Indonesia sehingga terhindar dari kesalahpahaman dalam penyampaian ide. Hal ini menjadi penting dalam media cetak yang dipublikasikan untuk khalayak ramai. Oleh sebab itu, surat pembaca merupakan objek penelitian yang menarik untuk diteliti lebih lanjut.

\section{METODE}

Metode yang digunakan adalah deskriptif analitik. Metode deskriptif diperuntukkan untuk memaparkan fenomena yang ada, baik fenomena yang bersifat alamiah ataupun rekayasa manusia (Sukmadinata, 2009:72 dalam Sari, 2017:55). Metode pengumpulan data yang digunakan adalah studi pustaka dengan teknik baca dan teknik catat. Metode dan teknik analisis data dalam penelitian ini digunakan metode deskriptif kualitatif dan metode agih disertai teknik dasar bagi unsur langsung (BUL) serta teknik ganti. Selanjutnya, metode dan teknik penyajian hasil analisis data digunakan metode formal dan informal disertai teknik deskriptif.

Menurut Nazir (1988:63), teknik deskriptif adalah teknik yang memaparkan atau menggambarkan secara teratur, faktual, cermat, mengenai fakta, sifat-sifat dan fenomena yang diteliti. Teknik ini digunakan dalam memilah data berdasarkan hal yang menjadi kajian dalam penelitian.

\section{HASIL DAN PEMBAHASAN}

\section{Kalimat Efektif}

Menurut Kridalaksana (2001:97) kalimat adalah kalimat adalah satuan bahasa yang relatif berdiri sendiri mempunyai pola intonasi final, baik secara aktual maupun potensial terdiri atas klausa. Kalimat efektif dikenal dalam hubungan fungsi kalimat selaku alat komunikasi (Razak, 1986:2). Kalimat efektif adalah kalimat yang 
bersifat padat, jelas, singkat, lengkap, dan dapat memberikan informasi secara tepat (Widjono, 2012: 205). Dapat disimpulkan bahwa kalimat merupakan satuan bahasa yang bersifat relatif berdiri sendiri, memiliki pola intonasi yang mengungkapkan gagasan seseorang secara terbuka, sedangkan kalimat efektif merupakan kalimat sebagai alat komunikasi yang memberikan sebuah gagasan, pikiran dan perasaan penulis kepada pembaca.

\section{Jenis Kalimat}

Kalimat yang digunakan pada surat pembaca memiliki jenis yang perlu diketahui agar menjadi kalimat yang efektif. Menurut Razak (1986:8) kalimat efektif terdiri atas struktur kalimat dan variasi kalimat yang dipaparkan di bawah ini.

\section{1). Struktur Kalimat}

\section{a. Kalimat Sederhana}

Kalimat sederhana adalah kalimat yang memiliki satu klausa. Kalimat sederhana mempunyai ciri-ciri lebih pendek dibandingkan dengan kalimat luas. Pada hakikatnya, kalimat sederhana memberikan satu informasi dan kalimat sederhana dapat dikelompokkan menjadi kalimat luas. Bentuk kalimat sederhana terlihat dari tuturan sang penulis yang sering digunakan dalam kehidupan sehari-hari. Kalimat sederhana merupakan dasar dari ragam kalimat yang secara alamiah sering digunakan sejak kecil, baik untuk tuturan maupun tulisan. Dari segi bentuk kalimat sederhana memiliki isi dan bentuk yang sederhana. Kalimat sederhana hanya menunjukkan satu informasi atau pikiran. Sepatutnya dalam berkomunikasi pemahaman struktur dan pola kalimat sangat penting untuk diperhatikan (Intikasari, 2014:167).

Baik kalimat sederhana maupun kalimat luas, dapat dilihat dari masalah struktur. Kalimat sederhana umumnya kebanyakan lebih pendek daripada kalimat luas. Kalimat sederhana berbentuk universal, berlaku di semua tempat dan waktu. Kalimat sederhana memiliki pola dasar kalimat yang sederhana, yang mempunyai dua unsur. Pertama, unsur yang dibicarakan, sedangkan yang kedua adalah unsur yang memiliki fungsi memberitahukan unsur yang dibicarakan. Ahli tata bahasa mengatakan bahwa dua unsur dasar kalimat sederhana adalah subjek dan predikat (Razak, 1986:20). Sebuah kalimat mampu disampaikan dengan baik oleh pembaca agar pembaca mengetahui hal yang dimaksud penulis. Dalam kalimat sederhana terdapat subjek dan predikat, sehingga perlu penambahan sejumlah kata agar mencapai kejelasan kalimat. Proses penambahan kata pada pola dasar disebut mengembangkan kalimat (Razak, 1986:23). Maksud mengembangkan kalimat adalah menambah unsur lain agar menjadi kalimat yang efektif.

\section{b. Kalimat Luas}

Kalimat luas adalah kalimat yang mempunyai dua klausa atau lebih. Ciriciri kalimat luas adalah kalimat yang berisi lebih dari satu informasi, kalimatnya lebih panjang daripada kalimat sederhana, dapat dilihat dari segi isi dan makna. Sebuah kalimat luas dapat terbentuk dari proses perangkaian dua kalimat sederhana atau lebih. Kalimat luas mempunyai struktur kalimat yang terbagi atas dua macam, yaitu sederhana dan kompleks atau majemuk. Kalimat luas terbentuk dari gabungan dua buah kalimat sederhana atau lebih. Jadi, kalimat luas dan kalimat sederhana saling berhubungan. Pola kalimat luas terdiri atas ruas-ruas dan masing-masing menyerupai sebuah kalimat sederhana (Razak. 1986:31).

Jumlah ruas dalam kalimat luas, bergantung pada jumlah informasi yang terdapat di dalamnya. Setiap ruas sebanding dengan banyaknya kalimat 
sederhana yang mendasari pembentukan kalimat. Dalam hubungan ini ada tiga macam ragam kalimat bahasa Indonesia dalam karya tulis (1) kalimat luas yang dihubungkan oleh situasi, (2) kalimat luas yang dihubungkan secara elips, dan (3) kalimat luas yang dihubungkan dengan kata atau kelompok kata tertentu yang bertugas sebagai penghubung (Razak, 1986:36). Perbedaan ketiga macam hubungan kalimat luas dapat dilihat dari segi situasi, unsur formal yang menghubungkan beberapa unsur kalimat sederhana menjadi kalimat luas, sedangkan hubungan elips dicantumkan satu unsur tertentu dan ruas lain kalimatnya hilang. Dari segi kata penghubung, penulis membuat kalimat luas dengan unsur formal yang diikuti kata penghubung.

Cara membangun kalimat luas yang efektif ialah mempelajari bentuk, sifat, serta fungsi kata penghubung, yang dapat digeser ke bagian tengah dan depan dalam sebuah kalimat luas. Menurut tata bahasa Indonesia, pergeseran kata penghubung disebut pergeseran sintaksis, sedangkan dari sudut prinsip kalimat efektif, jika terdapat kelebihan pemakaian kata disebut pemborosan yang tidak efisien.

\section{c. Kalimat Gabung}

Kalimat gabung adalah kalimat yang mempunyai unsur yang sama pada kalimat yang digabungkan menjadi satu. Kalimat gabung tidak dapat dikategorikan dalam kalimat sederhana dan kalimat luas karena setiap struktur kalimat memiliki prinsip yang tidak berubah-ubah. Dari segi isi kalimat, kalimat gabung dapat digolongkam pada kalimat luas, karena informasinya lebih dari satu. Dari segi struktur kalimat luas memiliki satu subjek dan predikat, sedangkan kalimat gabung memiliki struktur dan unsur yang sama digabung menjadi satu dalam kalimat. Dari sudut isi kalimat, kalimat gabung dapat dikategorikan ke dalam kalimat luas sebab informasinya lebih dari satu (Razak, 1986: 54). Jika dilihat dari sudut struktur, kalimat luas terdiri ruas-ruas yang berisi unsur subjek dan predikat, sedangkan kalimat gabung memiliki struktur dan terbentuk secara tersendiri.

\section{2). Variasi Kalimat}

Menurut Razak (1986:141) dengan memakai berbagai jenis kalimat dapat menjadikan berbagai variasi. Variasi kalimat terdiri atas kalimat tanya, kalimat seru, dan kalimat langsung yang akan dipaparkan di bawah ini.

\section{a. Kalimat Tanya}

Kalimat tanya merupakan kalimat efektif untuk menjadikan variasi kalimat dalam karya tulis, sebab menulis merupakan bentuk lain dari berbicara. Sebuah karangan akan lebih efektif jika ditulis dengan penulisan yang baik dan benar. Dalam menulis tentu seorang penulis tidak mengharapkan pertanyaan dari pembaca, tetapi hal ini tidak menghalangi penulis untuk menampilkan kalimat tanya dalam karangan. Pada kalimat tanya diawali dengan $5 \mathrm{~W}+1 \mathrm{H}$ dan diakhiri dengan tanda tanya. Dalam kalimat tanya juga diimbuhi dengan partikel -kah dan partikel -kan.

Kalimat tanya digunakan untuk membangkitkan perhatian pembaca. Agar kalimat terlihat hidup, penulis memberikan kalimat tanya dan pertanyaan itu dijawab sendiri atau diterangkan sendiri. Fungsi kalimat tanya dapat memberikan variasi pada kalimat.

\section{b. Kalimat Seru}

Kalimat seru adalah kalimat yang menunjukkan rasa kagum. Kalimat seru juga disebut dengan kalimat interjektif, yaitu kalimat yang menunjukkan pernyataan rasa marah. Kalimat seru juga dibentuk sebagai kalimat statif karena kalimat seru memiliki predikat yang bersifat adjektif dengan ditambah partikel 
-nya. Dalam sebuah karangan, kalimat seru tidak menunjukkkan perasaan haru pada pembaca sebab sebuah kalimat seru berguna mengungkapkan pandangan (ekspresi) atau emosional yang kuat.

\section{c. Kalimat Langsung}

Kalimat langsung dapat dikatakan jika pengarang mengatakan perkataan orang lain menurut apa adanya, tidak ada perubahan ataupun penambahan. Kalimat langsung ditandai oleh tanda kutip, baik pada permulaan kalimat maupun akhir kalimat. Kalimat langsung sering ditemukan dalam cerita fiksi. Artinya ucapan seorang pelaku dalam sebuah cerita fiksi dapat dituturkan dalam kalimat langsung. Apabila kalimat langsung dalam bentuk dialog antarpelaku, kalimat langsung tidak berfungsi sebagai pemberi variasi, tetapi merupakan suatu keharusan.

\section{3). Ciri-ciri Kalimat Efektif}

Menurut Widjono (2012:205), ciriciri kalimat efektif meliputi (1) keutuhan, (2) bentuk kata dan (atau) struktur kalimat secara gramatikal, (3) kalimat efektif meliputi kefokusan pikiran sehingga mudah dimengerti, (4) kehematan penggunaan unsur kalimat, (5) kecermatan dan kesantunan, dan (6) kevariasian kata dan struktur sehingga menghasilkan kebenaran bahasa.

\section{a. Keutuhan}

Keutuhan dalam kalimat harus menunjukkan ide pokok atau keselarasan antara subjek, predikat, objek, dan keterangan. Hal ini menunjukkan bahwa keutuhan kalimat harus memiliki gagasan pokok yang hendak disampaikan oleh pembaca. Keutuhan kalimat ditandai dengan kesepadanan struktur dan makna kalimat. Oleh karena itu, dalam penulisan kalimat efektif dilarang memakai kalimat yang panjang yang tidak memiliki unsur $\mathrm{S}$ dan P. Unsur tersebut ditandai dengan sekurang-kurangnya adanya subjek dan predikat (Devita dkk, 2020:64). Tetapi, unsur lain yang berupa objek, pelengkap dan keterangan tidak harus dicantumkan dalam kalimat. Bukan berarti bahwa bahasa dalam kalimat tidak diperlukan unsur tersebut. Oleh karena itu, unsur objek, pelengkap dan keterangan bersifat mana suka.

\section{b. Kesejajaran}

Kesejajaran adalah kemiripan bentuk kata yang digunakan secara tetap dalam satu kalimat. Kalimat efektif memiliki ketentuan adanya kesejajaran unsur atau bagian dalam kalimat (Listika dkk, 2019:186). Kesejajaran atau paralelisme berarti menempatkan gagasan dan fungsi yang sepadan dalam satu struktur atau konstruksi gramatikal. Gaya pararelisme digunakan untuk memperindah sebuah kalimat. Sebaliknya, kalimat yang tidak memedulikan keindahan dan keselarasan akan terasa kurang dan tidak seimbang dalam menyampaikan gagasan. Jika salah satu gagasan menggunakan kata benda, kata atau kelompok kata yang lain yang menempati fungsi yang serupa harus ditempatkan dalam kata benda. Jika disejajarkan dengan kata kerja yang lain, maka ditempatkan juga dalam kata kerja dan seterusnya.

\section{c. Kefokusan}

Kalimat efektif memfokuskan pesan yang penting agar mudah dimengerti oleh pembaca. Jika tidak, makna kalimat akan susah dipahami dan menghambat komunikasi sehingga kalimat menjadi bertele-tele. Kefokusan kalimat, penting digunakan agar terhindar dari ketidakefektifan kalimat dan pemborosan kata dalam kalimat.

\section{d. Kehematan}

Dalam ciri-ciri kalimat efektif terdapat kehematan kalimat yang dimaksudkan untuk menanggung kehematan kalimat. Artinya, setiap unsur atau bagian kalimat harus berguna dengan baik, kata yang berlebihan harus dihindari. Hal yang tidak mendukung 
kehematan kalimat adalah subjek ganda, penjamakan kalimat, dan penggunaan bentuk singkat. Kehematan dapat dilakukan jika pemakaian kata, frasa atau kelompok kata berlebihan.

\section{e. Kecermatan dan Kesantunan}

Kecermatan kata dalam kalimat ditetapkan oleh ketepatan pilihan kata, penyusunan kata, dan penggunaan logika dalam kalimat. Banyak kata dalam bahasa Indonesia memiliki makna yang hampir mirip dan sering dikatakan sebagai kata yang bersinonim atau menimbulkan tafsiran ganda. Dipihak lain kesantunan kalimat memuat makna bahwa gagasan yang diekspresikan dapat menjadikan suasana atau hubungan dengan baik. Kalimat yang santun ditandai dengan kalimat yang bersifat singkat, jelas, lugas, dan tidak berbelitbelit.

\section{f. Kevariasian}

Kevariasian kalimat dapat diterapkan dengan variasi diksi, struktur, dan gaya. Dengan syarat variasi tersebut tidak menyebabkan perubahan makna kalimat yang mengakibatkan kesalahpahaman. Untuk menyampaikan efektivitas sebuah kalimat berita atau pertanyaan dapat disampaikan dalam kalimat tanya dan kalimat perintah. Kevariasian kalimat digunakan agar informasi terihat menarik dan kalimat yang disajikan tidak terlihat datar sehingga pembaca tidak bosan. Jika penulis memakai kalimat yang panjang atau pendek secara berulang-ulang, pembaca akan merasa kelelahan dan kehilangan gagasan atau ide pokok.

\section{g. Ketepatan Diksi}

Penggunaan bahasa yang benar menurut kaidah Ejaan Yang Disempurnakan (EYD) merupakan salah satu hal yang sangat penting dalam hal tulis-menulis (Qhadafi 2018:1). Ketepatan diksi atau pilihan kata dalam kalimat agar terlihat efektif harus membedakan kata yang bersinonim, struktur idiomatik, kata yang berlawanan makna, ketepatan atau kesesuaian, dan sebagainya. Ketepatan diksi digunakan untuk memberikan gagasan dengan menjadikan kata yang tepat dalam suatu situasi. Penggunaan ketepatan diksi atau pilihan kata digunakan untuk mengomunikasikan ide pokok dengan menggunakan diksi yang sesuai dengan kaidah bahasa Indonesia dengan tujuan agar terhindar dari kesalahan makna.

\section{h. Ketepatan Ejaan}

Ketepaan ejaan dan tanda baca dapat memastikan kualitas penyajian data dalam kalimat. Sebaliknya, kesalahan ejaan dapat mengakibatkan kesalahan komunikasi yang fatal dalam kalimat sehingga menjadi kesalahpahaman dan kalimat menjadi tidak efektif. Ejaan adalah aturan bahasa dengan tujuan memakai huruf, kata, dan tanda baca secara tepat. Penulis harus mengetahui penggunaan ketepatan ejaan yang sesuai dengan kaidah bahasa Indonesia, terutama dalam bahasa tulis misalnya penulisan pada surat pembaca. Ketepatan ejaan akan berimplikasi pada kejelasan makna.

\section{Ketidakefektifan Kalimat dalam Surat Pembaca Bali Post Periode Januari- Agustus 2020}

Keefektifan sebuah kalimat ditandai dengan ketepatan kalimat yang menunjukkan gagasan penulis dan mengakibatkan gagasan yang tepat dalam pikiran pembaca. Sebaliknya kalimat yang strukturnya campur aduk, tidak mewujudkan kesatuan apapun dan merupakan suatu pernyataan yang kosong disebut kalimat tidak efektif (Razak, 1986:7). Kalimat yang pola strukturnya salah menurut tata bahasa, jelas tidak efektif (Razak, 1986:3).

Analisis ketidakefektifan kalimat pada surat pembaca Bali Post tahun 2020 dalam pembahasan ini difokuskan pada 
tiga hal yaitu jenis kalimat efektif, ciriciri kalimat efektif, dan bentuk-bentuk ketidakefektifan kalimat. Ketiga subbab tersebut dianalisis berdasarkan data yang ditemukan dalam surat pembaca Bali Post (Juli--Agustus) 2020.

\section{Kesalahan Struktur}

Kesalahan berbahasa tidak sekedar ditemukan pada tuturan, tetapi juga ditemukan pada bahasa tulis (Antari, 2017:47). Salah satu kesalahan dalam kalimat adalah kesalahan struktur. Berikut contohnya.

\begin{tabular}{|c|c|c|}
\hline No & $\begin{array}{l}\text { Kalimat tidak } \\
\text { efektif }\end{array}$ & Perbaikan \\
\hline 1 & $\begin{array}{l}\text { Hari Senin pagi } \\
30 \text { Desember } \\
\text { belum lama ini } \\
\text { saya mampir ke } \\
\text { gedung Budaya } \\
\text { Kota Denpasar } \\
(\mathrm{SP}, 06 / 01 / 20)\end{array}$ & $\begin{array}{l}\text { Senin pagi } \\
30 \\
\text { Desember } \\
\text { belum lama } \\
\text { ini, saya } \\
\text { mampir ke } \\
\text { gedung } \\
\text { Budaya } \\
\text { Kota } \\
\text { Denpasar. }\end{array}$ \\
\hline 2 & $\begin{array}{l}\text { Di Bali sendiri } \\
\text { ada puluhan, } \\
\text { bahkan seratusan } \\
\text { petani yang } \\
\text { mengggantungka } \\
\text { n hidupnya dari } \\
\text { produksi arak } \\
\text { Bali } \\
(\mathrm{SP}, 30 / 01 / 20) .\end{array}$ & $\begin{array}{l}\text { Ada } \\
\text { puluhan } \\
\text { bahkan } \\
\text { ratusan } \\
\text { petani di } \\
\text { Bali yang } \\
\text { menggantun } \\
\text { gkan } \\
\text { hidupnya } \\
\text { dari } \\
\text { produksi } \\
\text { arak Bali. }\end{array}$ \\
\hline
\end{tabular}

Kalimat di atas merupakan contoh dari kesalahan struktur kalimat. Pada kalimat (1) terdapat kata "hari Senin" kata "Senin" sudah menunjukkan hari. Jadi, kata "hari" dihilangkan. Sebaliknya, pada kalimat (2) ftasa preposisional "di Bali" ditempatkan pada awal kalimat. Agar lebih efektif frasa "di Bali" ditempatkan setelah subjek.

\section{Kerancuan Kalimat}

Kalimat rancu disebabkan oleh gagal nalar, sehingga menimbulkan multiftafsir. Kalimat yang memenuhi penalaran artinya kalimat yang secara nalar dapat diterima atau kalimat yang diterima oleh akal sehat.Kalimat yang seperti ini akan dipahami dengan mudah, cepat, tepat, dan tidak menimbulkan salah pengertian (Futih, 2016:5).

\begin{tabular}{|c|c|c|}
\hline No & $\begin{array}{c}\text { Kalimat tidak } \\
\text { efektif }\end{array}$ & Perbaikan \\
\hline 1 & $\begin{array}{l}\text { Sayangnya, } \\
\text { peraturan tersebut } \\
\text { baru dirasakan } \\
\text { hanya pada toko- } \\
\text { toko atau } \\
\text { minimarket, } \\
\text { sehingga } \\
\text { timbullah } \\
\text { pertanyaan; } \\
\text { kenapa di pasar- } \\
\text { pasar tradisonal } \\
\text { masih marak } \\
\text { penggunaan } \\
\text { kantong plastik } \\
\text { yang kemudian } \\
\text { akan menjadi } \\
\text { sampah plastik? } \\
\text { (SP, 03/01/20) }\end{array}$ & $\begin{array}{l}\text { Sayangnya } \\
\text {, peraturan } \\
\text { tersebut } \\
\text { baru } \\
\text { dirasakan } \\
\text { oleh toko- } \\
\text { toko atau } \\
\text { minimarke } \\
\text { t sehingga } \\
\text { timbullah } \\
\text { pertanyaan } \\
\text {; mengapa } \\
\text { di pasar } \\
\text { tradisonal } \\
\text { masih } \\
\text { marak } \\
\text { penggunaa } \\
\text { n kantong } \\
\text { plastik } \\
\text { yang } \\
\text { kemudian } \\
\text { akan } \\
\text { menjadi } \\
\text { sampah } \\
\text { plastik? }\end{array}$ \\
\hline 2 & $\begin{array}{l}\text { Dan dalam } \\
\text { penggunaan } \\
\text { selama enam } \\
\text { bulan, lampu lalu } \\
\text { lintas ini mati } \\
\text { kembali } \\
09 / 01 / 20) .\end{array}$ & $\begin{array}{l}\text { Dalam } \\
\text { penggunaa } \\
\text { n selama } \\
\text { enam } \\
\text { bulan, } \\
\text { lampu lalu } \\
\text { lintas mati } \\
\text { kembali. }\end{array}$ \\
\hline
\end{tabular}

Dalam kalimat (1) dan (2) terdapat kerancuan kalimat. Kerancuan kalimat pada kalimat (1) dilihat dari kata "hanya 
pada" dan " di pasar-pasar". Pada frasa "hanya pada" dapat diganti dengan kata "oleh" dan frasa "di pasar-pasar" cukup ditulis "di pasar". Pada awal kalimat (2) terdapat kata " dan dalam". Seharusnya, cukup digunakan kata "dalam", sedangkan kata "dan" dihilangkan untuk menghindari kerancuan kalimat. Kalimat tanya "kenapa" lebih efektif jika diganti dengan kalimat tanya "mengapa".

\section{Kesalahan Diksi}

Setiap menulis, pilihan kata haruslah tepat. Pilihan kata yang digunakan harus mampu mewakili gagasan secara benar dan sesuai yang membuat gagasan yang sama pada pikiran pembacanya (Hidayatullah 2018:42).

\begin{tabular}{llll}
\hline No & Kalimat & \multicolumn{2}{l}{ Perbaikan } \\
& tidak efektif & \\
\hline 1 & Jangan sampai & \multicolumn{2}{l}{ Jangan sampai } \\
& krisis air menjadi & krisis air \\
& momok yang & menjadi \\
buruk terhadap & momok yang \\
& citra pariwisata & buruk \\
& Nusa Penida, di & terhadap citra \\
& mana & pariwisata \\
& masyarakatnya & Nusa Penida \\
& "kelaparan" air & yang \\
& bersih $\quad$ (SP, & masyarakatnya \\
& 22/01/20). & kekurangan air \\
& & bersih. \\
\hline
\end{tabular}

Pada kalimat di atas terdapat kesalahan diksi, yaitu kata tanya "di mana" yang terletak di dalam kalimat dan lebih efektif jika diganti dengan "yang"

\section{Kesalahan Ejaan}

\begin{tabular}{lll}
\hline No & $\begin{array}{l}\text { Kalimat } \\
\text { tidak efektif }\end{array}$ & Perbaikan \\
\hline 1 & Guna & Untuk \\
& memeriahkan hari & memeriahkan \\
& Pangerupukan & hari \\
& Maret mendatang, & Pangerupukan \\
& Sekaa Teruna & Maret \\
& Teruni (STT) di & mendatang, \\
\hline
\end{tabular}

$\begin{array}{ll}\text { kabupaten } & \text { Sekaa Teruna } \\ \text { Badung membuat } & \text { Teruni (STT) } \\ \text { ogoh-ogoh sebaik } & \text { di Kabupaten } \\ \text { mungkin (SP, } & \text { Badung } \\ 07 / 02 / 20) . & \text { membuat } \\ & \text { ogoh-ogoh } \\ & \text { sebaik } \\ & \text { mungkin. }\end{array}$

Pada kalimat di atas terdapat ketidaktepatan ejaan. Ketidaktepatan ejaan terjadi karena terdapat kata yang terpengaruh dari bahasa asing dan daerah yang penulisannya tidak dicetak miring. Untuk menghindari hal tersebut kata yang terpengaruh, baik bahasa daerah maupun bahasa asing, wajib dicetak miring atau diberi tanda petik. Pada awal kalimat digunakan kata "guna" lebih efektif jika diganti dengan kata "untuk".

\section{Faktor-Faktor Kalimat \\ Ketidakefektifan}

Untuk menghindari kalimat tidak efektif perlu memerhatikan beberapa faktor penyebab ketidakefektifan kalimat. Putrayasa (2010:101) ketidakefektifan kalimat dapat disebabkan oleh beberapa faktor. Faktor-faktor tersebut meliputi (a) kontaminasi atau kerancuan, (b) pleonasme, (c) ambiguitas, (d) ketidakjelasan unsur kalimat, (e) kemubaziran preposisi, (f) kesalahan nalar, (g) ketidaktepatan bentuk kata, (h) ketidaktepatan makna kata, (i) pengaruh bahasa daerah, dan (j) pengaruh bahasa asing. Teori ini digunakan sebagai acuan untuk menganalisis faktor-faktot penyebab ketidakefektifan kalimat yang beberapa faktor dijelaskan sebagai berikut.

\section{Kontaminasi dan Kerancuan}

Kontaminasi ialah suatu perihal bahasa. Dalam bahasa Indonesia distilahkan dengan kerancuan. Rancu berarti kacau atau campur aduk. Jadi, kerancuan berarti kekacauan (Putrayasa, 2010:101). Kalimat dapat dikatakan 
rancu, jika susunan, perserangkaian, dan penggabungannya tidak sesuai atau tidak berpasangan. Kalimat yang rancu berarti susunan kalimatnya tidak berurutan sehingga informasi yang didapat sulit dipahami. Kerancuan kalimat bisa terjadi jika dua gagasan ditempatkan ke dalam satu proses pengungkapan.

\begin{tabular}{llll}
\hline $\begin{array}{l}\text { Kalimat tidak } \\
\text { efektif }\end{array}$ & Perbaikan & \\
\hline 1. & Mudah-mudahan & Dalam hal ini \\
ke depan Bali & mudah- \\
memang punya & mudahan ke \\
komitmen yang & depan Bali \\
jelas dalam hal & mempunyai \\
ini (SP, 20/01/20) & $\begin{array}{l}\text { komitmen yang } \\
\text { jelas. }\end{array}$ \\
\hline
\end{tabular}

\section{Pleonasme}

Pleonasme berarti penggunaan katakata yang berlebihan. Kalimat yang menggunakan kata yang berlebihan dapat disebut kemubaziran kalimat. Kemubaziran kalimat dapat terjadi, jika terdapat pemakaian dua kata yang sama arti. Dua kata yang searti tidak harus digunakan keduanya, tetapi cukup salah satu yang digunakan agar terhindar dari pemborosan kata. Menurut Badudu dalam Putrayasa (2010:106) yaitu, perihal pleonasme muncul karena beberapa kemungkinan, yaitu (a) pembicara tidak menyadari bahwa apa yang diucapkannya memuat sifat berlebihan, artinya dikerjakan tanpa sengaja, (b) dikerjakan bukan karena tidak sengaja, melainkan karena tidak mengetahui bahwa kata-kata yang digunakan mengungkapkan pengertian yang berlebihan, dan (c) dikerjakan dengan sengaja sebagai salah satu bentuk gaya bahasa untuk menyerahkan tekanan pada arti (intensitas). Selain dua hal di atas ada juga ambiguitas, ketidakjelasan unsur kalimat, kemubaziran preposisi, kesalahan nalar, ketidaktepatan bentuk kata, ketidaktepatan makna, pengaruh bahasa daerah dan pengaruh bahasa asing.

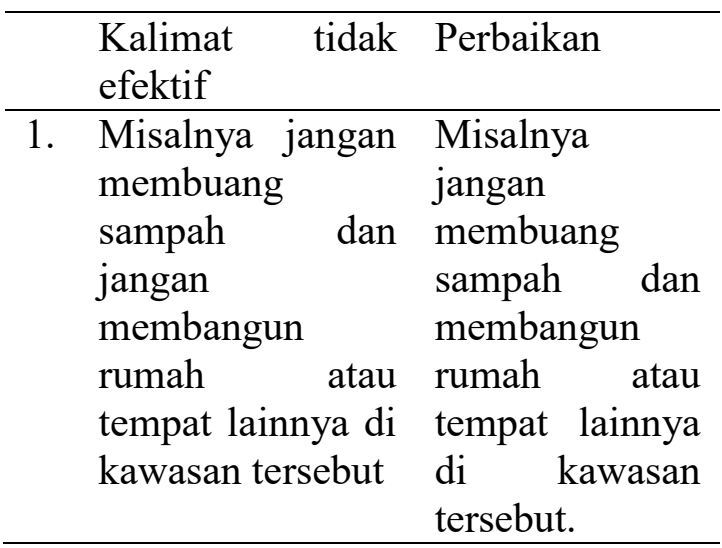

\section{SIMPULAN}

Berdasarkan hasil analisis, ditemukan simpulan yang berkaitan dengan penggunaan kalimat efektif pada surat pembaca Bali Post 2020. Simpulan dalam penelitian ini dipaparkan sebagai berikut.

Dari hasil analisis penggunaan kalimat efektif pada surat pembaca Bali Post tahun 2020 ditemukan ketidakefektifan kalimat sebanyak delapan kalimat yang terdiri atas struktur kalimat dan variasi kalimat. Ciri-ciri kalimat efektif ditemukan sebanyak delapan bentuk yang meliputi (a) keutuhan, (b) kesejajaran, (c) kefokusan, (d) kehematan, (e) kecermatan dan kesantunan, (f) kevariasian, (g) ketepatan diksi, dan (h) ketepatan ejaan. Selain itu, bentuk-bentuk ketidakefektifan kalimat pada surat pembaca Bali Post tahun 2020 terdiri atas kesalahan kalimat, kesalahan struktur, kerancuan kalimat, kesalahan diksi, dan kesalahan ejaan. Hal tersebut menunjukkan bahwa penggunaan kalimat dalam surat pembaca Bali Post 2020 belum memenuhi keefektifan kalimat.

Ketidakefektian kalimat dalam surat pembaca Bali Post 2020 disebabkan oleh beberapa faktor. Adapun faktor-faktor penyebab ketidakefektifan kalimat yang meliputi (a) kontaminasi atau kerancuan, (b) pleonasme, (c) ambiguitas, (d) ketidakjelasan unsur kalimat, (e) kemubaziran preposisi, (f) kesalahan nalar, (g) ketidaktepatan bentuk kata, (h) ketidaktepatan makna kata, (i) pengaruh bahasa daerah, dan (j) pengaruh bahasa 
asing. Hal ini menunjukkan bahwa penggunaan kalimat dalam surat pembaca Bali Post tahun 2020 belum efektif. Artinya, terdapat ketidakefektifan kalimat.

Penelitian ihwal kalimat efektif masih dapat dikaji lebih jauh lagi menggunakan pelbagai perspektif bidang keilmuan. Kajian-kajian mendalam perihal surat pembaca akan berdampak baik pada dinamika eksistensi surat pembaca di masyarakat.

\section{DAFTAR PUSTAKA}

Antari, Wayan \& Made Sri Satyawati. 2017. "Analisis Penggunaan Kalimat Bahasa Indonesia pada Karangan Siswa Kelas V Sekolah Dasar Negeri 10 Sanur, Denpasar" Jurnal Humanis, Fakultas Ilmu Budaya Unud Vol 21. No1 Nopember: $46-51$.

Ardian, Muhammad Imron, 2017. "Analisis ketidakefektifan kalimat dalam karangan siswa hasil pembelajaran menulis petunjuk di SMP 3 Kedungwuni" Jurnal Lingtera Vol. 4 No.2: 163-176.

Astuti, Sri Budi. 2015. "Ketidakefektifan Kalimat dalam Jurnal Ilmiah Linguistik Indonesia Edisi Tahun 2013" Jurnal Wahana Vol. 65 No.2.

Devita, Marieta Bona dkk. 2020 "Kajian Kalimat Efektif pada Laporan Berita Reporter Metro TV" Jurnal Humanis Vol. 24. No.1.

Effendy, Onong Uchana. 1993. Ilmu, Teori dan Filsafat Komunikasi. Bandung: PT Citra Aditya Bakti.

Faraba, Karina Sofianfa Armaza dkk, 2017 "Pelesapan Subjek dan Predikat pada Judul-Judul Berita Line News Populer" Jurnal Pena
Indonesia Vol. 3 No. 1.

Futih, Febriani Fatiha Falahallaily. 2016. Artikel Publikasi Ketidakefektifan Kalimat pada Wacana dalam Buku Paket Mandiri Bahasa Indonesia untuk Smp/Mts Kelas VII Surakarta: Pendidikan Bahasa dan Sastra Indonesia Fakultas Keguruan dan Ilmu Pendidikan Universitas Surakarta.

Hariyanto, Prima. 2018. "Ketidakefektifan Kalimat dalam Tulisan Guru SD" dalam Jurnal Metalingua, Vol. 16 No. 1.

Hidayatullah, Ahmad. 2018 "Analisis Kesalahan Diksi pada Karangan Siswa Kelas IX SMP Islam Daar El-Arqam Tangerang" Junal ElBanar Vol.1 No. 1.

Intikasari, Suhardini. 2014 "Peningkatan Kemampuan Menulis Kalimat Sederhana Melalui Media Keping Kata Bergambar pada Siswa Tunarungu di SDLB" Jurnal Ortopedagogia, Vol. 1 No. 2, Juli: $166-173$.

Keraf, Gorys. 1980. Komposisi (Sebuah Pengantar Kemahiran Bahasa). Ende Flores : Nusa Indah.

Kridalaksana, Harimurti. 2001. Kamus Linguistik. Jakarta: Gramedia Pustaka Utama.

Listika Mega, dkk. 2019 "Penggunaan Kalimat Efektif pada Artikelopen Journal System (Ojs) Korpus" Jurnal Ilmiah Korpus, Vol. 3, No. 2.

Putrayasa, Ida Bagus. 2010. Kalimat Efektif (Diksi, Struktur, dan Logika). Bandung: PT Refika Aditama. 
Rahmat. 2017. "Ketidakefektifan Ragam Bahasa Jurnalistik Majalah Makassar Terkini" Edumaspul Jurnal Pendidikan, No. 1 Vol.2: $71-80$.

Razak, Abdul. 1986. Kalimat Efektif (Struktur, Gaya, dan Variasi). Jakarta: PT. Gramedia.

Sari, Kartika. 2017 "Kerancuan Kalimat dalam Tulisan Siswa SMA 1 Sijunjung Jurnal Metalingua, Vol. 15 No. 1, Juni:53--62.

Suyamto. 2016. "Ketidakefektifan Kalimat dalam Jurnal Fluida Volume II No.2, November Polban 2015" dalam Jurnal Sigma-Mu Vol 8 No. 1.

Tarigan, Henry Guntur. 1985. PrinsipPrinsip Dasar Sintaksis. Bandung: Angkasa.

Tarigan, Henry Guntur. 2008. Berbicara sebagai Suatu Keterampilan Berbahasa. Bandung: Angkasa.

Tarigan, Henry Guntur. 2009. Pengajaran Sintaksis. Bandung: Angkasa.

Wardani. Kusuma. 2016. "Analisis Kesalahan Berbahasa pada Bidang Sintaksis dan Karangan Deskripsi Siswa Kelas X SMK Pelita Bangsa Boyolali. Universitas Muhammadiyah Surakarta.

Widjono. 2012 . Bahasa Indonesia. Jakarta: PT Grasindo. 